\title{
Analysis on The Impact of Modernization of Tax Administration on Taxpayers' Satisfaction on Large Tax Office 2
}

\author{
Devi Yanty ${ }^{1}$ and Milla Sepliana Setyowati ${ }^{2}$ \\ \{deviyanty12@gmail.com¹ and milla.s.setyowati@gmail.com² \\ Universitas Indonesia, Indonesia ${ }^{1,2}$
}

\begin{abstract}
Modernization of tax administration with public-oriented concept has been conducting since 2002 where Large Tax Office was taken as the pilot project. This research is conducted to analyze the implementation of tax administration modernization on Large Tax Office 2 as well as analyzing the impact on taxpayers' satisfaction. This research employs mixed methods. In quantitative side, this research employs descriptive statistic test, regression test, and coefficient determination test on data collected through questionnaire. In qualitative side, this research conducted in-depth interview to do crosschecking and help interpret the quantitative result. The result shows that tax modernization in Large Tax Office 2 has been running well and successful to provide satisfaction to taxpayers. Suggestion of this research is that Large Tax Office 2 needs to maintain and to improve service quality by embedding optimal services to be proactively responsive taxpayers as well as proactively evaluating weakness and challenges that may come up from taxpayers' complaints.
\end{abstract}

Keywords: Taxpayers' Satisfaction, Modernization of Tax Administration, Tax Services

\section{Introduction}

Tax is basically a fundamental support for the government revenue. Government institution mandated to formulate and run tax policy as well as its administration process is Directorate General of Tax (DGT) under Ministry of Finance. In performing the tasks, DGP keeps improving policy and regulation as well as its services and administration. These improvements are well-known as administration reform. Tax reform is executed due to strong demands from taxpayers upon services they perceived.

Basically, tax reform is conducted to move towards better improvement. Through comprehensive tax reform, development would be more sustainable. Nevertheless, in reality tax system in Indonesia still below other countries in ASEAN. The following is table of ranking of ease of paying tax. 
Table 1. Ranking of Ease of Paying Tax of ASEAN Countries

\begin{tabular}{llll}
\hline \multicolumn{1}{c}{ Negara } & 2014 & 2015 & 2016 \\
\hline Singapore & 5 & 5 & 5 \\
Brunei Darussalam & 20 & 30 & 16 \\
Malaysia & 36 & 32 & 31 \\
Thailand & 70 & 62 & 70 \\
Myanmar & 107 & 116 & 84 \\
Cambodia & 65 & 90 & 95 \\
Philippines & 131 & 127 & 126 \\
Lao & 119 & 129 & 127 \\
Indonesia & 137 & 160 & 148 \\
Vietnam & 149 & 173 & 168 \\
\hline
\end{tabular}

Source: Word Bank and PwC in MoF Indonesia

According to the above table, it can be seen that Indonesia ranked 148 in 2016 in terms of ease of paying tax. Indonesia is, indeed, way below Singapore, Malaysia, and Thailand. Therefore, Directorate General of Tax needs improvement in terms of tax system to provide user-friendly procedure of tax payment. Besides tax paying ranking, tax reform is also urgent to improve image and credibility of DGT in the eyes of taxpayers. Therefore, the Minister of Finance Sri Mulyani has established special team for tax reform in 2017, with the ultimate goal to increase the government revenue. Since 2002, tax administration reform in the form of modernization has been gradually attempted by DGT to achieve comprehensive tax reform. According to Pandiangan [1], tax modernization is a grand design of tax reform.

Good tax administration basically does not only focus on the government revenue and ignore other aspects, but also how to improve the revenue. Through reforms that would be impactful to changes on system, services, and other tax-related aspects including tax system modernization, the state revenue is expected to positively grow. One of important aspects to consider is satisfaction of taxpayers. Public would perceive increase in prosperity. When that happens, there would be many demands from the public. Those demands are improvement in participation rate, transparency, and accountability of the government in the policy formulation in the State Revenue and Spending (APBN). According to Sang et al (2009) and Pinho et al [2], it would also drive the government of improve technology utilization in public sector.

According to Kotler, satisfaction is not only a problem of marketing, but it also matters for all departments. If analogous to a company, DGT has a responsibility to prioritize satisfaction of taxpayers. If the taxpayers complain about service standard from tax officials and administration, it would discourage taxpayers to deal with tax administration, then it would eventually hamper the attempt to increase government revenue. Referring to the problems, taxpayers' satisfaction is considered a serious matter by DGT. It is shown by many integrated surveys conducted by tax offices in many areas. The survey is addressed to measure taxpayers' satisfaction on services provided by tax offices and on all administration aspects such technology utilization in delivering services and ease of paying tax.

Object of this research is Large Tax Office 2. This tax office is chosen because it serves to handle large tax payments as well as serving as pilot project of tax administration modernization. 
Large Tax Office 2 earns the largest tax revenue and is the first to implement e-Bukpot compared to other Large Tax Offices.

Objective of this research is to analyze the implementation of tax administration modernization on Large Tax Office 2 through organization restructuration, management of human capital, computerization, and legal certainty. This research is also addressed to analyze the impact of tax administration modernization on taxpayers' satisfaction registered in Large Tax Office 2. According to above problems, it can be constructed the following research problems.

1. How is the implementation of tax administration modernization in Large Tax Office 2?

2. How is the impact of tax administration modernization on taxpayers' satisfaction registered in Large Tax Office 2?

\section{Literature Review}

\subsection{Modernization of Tax Administration}

This research refers to related information on tax administration modernization and taxpayers' satisfaction. The references consist of journals and working papers. According to Bird [3] the concept of administration reform is to keep it simple, taxpayer as the client, and computerization.

First important element of tax administration reform is to simplify the tax system. It is addressed to make the system effective in developing countries with low level of tax compliance. This procedure simplification can be applied to the existing procedures, such as eliminating redundant information request on letter of notification (SPT) and tightening purchase and return invoices. After having simplification, tax administration would carry out the task effectively in helping taxpayers to comply, to supervise, and to deal with noncompliance.

The second element of tax administration reform is the improvement of services. The improvement can be in the form of clear instruction, understandable forms, and help services as well as information center needed by taxpayers. In supervising compliance, it is needed sufficient information system management that covers taxpayers and third party (such as bank) as well as sufficient information and proactive responses in detecting and dealing with taxpayers who do not comply the tax provisions.

The third important element of tax administration reform is computerization. The computerization is addressed to redesign and to simplify tax system and procedure. Besides that, required forms and information would be simple. Experiences from some countries successful computerization requires fundamental reorganization on system and procedure. Sophisticated computerization system would not even be successful without any real incentive to use the system properly.

Nasucha [4] expressed required improvement in tax administration reform includes organization structure, organization procedure, organization strategy, and organizational culture. In organization structure, there six required elements to implement when designing organization structure such as job segmentation and specialization. Moreover, it also requires departmentalization through job classification so that coordination among jobs with the same nature would be more effective and efficient to do. In the other hand, chain of command is also required through top management to the lowest level of the organization in the form of reporting, 
as well as span of control through number of subordinates that can be directed effectively and efficiently. Furthermore, centralization and decentralization are also required in an organization where decision is taken from a single point within the structure. The last one, is formalization through job standardization in the organization.

Organization procedure needs to simple in terms of communication process, decision making, achievement selection process, as well as socialization and career process. Important things to consider in formulating organization strategy is definition of strategy and the urgency of strategy in an organization, relevance between organization structure, and considerations of formulated organization strategy towards decisions taken by the management. Moreover, organization culture is needed to shape particular behavior of organization member. Strong organization culture is reflected from values within the organization.

According to Jenkins and Khadka [5], there are important points to consider in enforcing modernization of tax administration in some developing countries. Those are unification of functional organizations, human capital development, modern administrative details, computerization, education program for taxpayers, complete and comprehensive tax regulations, and efficient appeal system. Though unification of functional organization, tax administration would be effectively structured based on tax classification or functions.

Through development of human capital, tax administration is required to establish specialist tax services to motivate tax officials to develop career in tax administration. Tax administration is also required to provide theoretical and practical trainings to tax officials in terms of all aspects of tax law and regulations. Besides that, tax administration also needs to increase salary of tax officials, improve behavior of tax officials to be more service-oriented, as well as improving staff management by conducting performance-based evaluation.

Through computerization, tax administration would be able to provide various services such as e-registration, e-SPT, r-refund, computerized accounting system, and e-filling. Computerization is important as it would serve automatic administrative activities and reduce potential political intervention (corruption, collusion, and nepotism). Besides that, computerization would also reduce the possibility of negotiation between tax officials and taxpayers as information turns to be systematic and transparent.

Through education program for taxpayers, they would be able to understand their tax obligations and rights, as well as due date to settle their tax payment. Activities of tax education program can be run in the form of brochure, tax poster, tax dialogue session, tax interaction program, tax seminar, radio and television education programs, and article publication and advertisement. These publications should also cover interpretations of law and changes on tax procedures.

Law certainty is required, but it tends to be complex but not that matter in developing countries. With strong law enforcement, tax authority can effectively impose sanctions to those who do not perform tax report, tax notification letter (SPT) report, and tax payment. Law enforcement system is strongly required in tax administration modernization in the form of simple and transparent tax regulation that is easy to implement by tax officials, specific sanction (fines) upon specific act, automatic calculation on interest, fines and tax payable through computer system, and consistent sanction (fines).

In general concept expressed by Pandiangan, modernization of tax administration basically includes organization restructuration, business process improvement through utilization of communication and information technology, and improvement in management of human capital. In organization restructuration, Pandiangan argued that it could be done by debureaucratization of tax-related functions, separation between audit and objection/appeal 
functions, taxpayers' segmentation (operational level) managed by tax offices, as well as internal audit and change program that are efficient and customer-oriented.

\subsection{Taxpayers' Satisfaction}

Abadi et al [6], model of DeLone and McLean (2003) is successful information and communication system to measure satisfaction. According to DeLone and McLean (2003) in Chen [7] service quality is antecedent of user's satisfaction. Model of DeLone and McLean (2003) adopted information quality, system quality, and service quality as antecedents of user's satisfaction. Saha et al (2012) in Puthur et al [8] indicators to measure quality of electronic information services are information accuracy, timeliness, and completeness. According to Nelson, Todd, and Wixom [9], accuracy is a condition where information is not bias, not ambiguous, reliable, and consistent. Completeness means all the things relevant and needed by users are available in the information. Currency means information is always actual and updated to reflect current condition.

Chen the quality of system is measurement of the information system. In line with the quality of information, the quality of system itself consists of accessibility, interactivity, and ease of use. Accessibility is speed of access and system availability adopted from quality of system. Yang et al [10], there would be no comfort in using website as information center without any accessibility. The accessibility consists of availability and responsiveness. Customers or users expect responsive, accessible, and downloadable information services all the time. According to Palmer [11], interactivity is the ability to adjust appearance, nuance, and content of a website, as well as providing relevant interaction with users.

Doll and Torkzadeh [12], if users perceived an application is easy to use, they would be expert and able to optimize the use of benefits from the application. Besides that, ease of use can also improve productivity and enable decision makers to have better decision alternatives. According to Rai et al [13] quality of system is measured using ease of use indicator in many researches. According to Doll and Torkzadeh and Rai et, ease of use indicator is defined as a situation where an application is perceived to be easily used. Ilhaamie [14] quality of service is an important dimension in measuring performance of organization in public sector as it serves as the core output of the organization. According to Ilhaamie, the most dominant instrument in measuring service quality is SERVQUAL expressed by Parasuraman et al [15]. SERVQUAL consists of 10 dimensions, and was simplified into 5 dimensions. They are tangibility, reliability, responsiveness, assurance, and empathy.

Parasuraman et al, there are some factors to evaluate satisfaction using SERVQUAL. Those factors are tangibility, reliability, responsiveness, assurance, and empathy. Tangibility consists of physical aspect, equipment, and communication channels. Reliability consists of the ability to provide services faster, accurately, and satisfying. Responsiveness means intention from staff to proactively deliver services and to provide help to customers. Assurance includes characteristics and competencies of staff such as knowledge, capability, courtesy, integrity, and risk-free. Empathy consists of ease of building communication, concern from service providers, and ability to understand what customers actually need.

$\mathrm{Hu}$ et al [16] measured service quality by adopting 22 instruments of SERVQUAL in the context of e-tax services. Based on prior researches, SERVQUAL is the most common concept to measure service quality that enables variation in the context of information system and online service quality. According to the above descriptions, previous researches revealed that SERVQUAL can be used to measure service quality both in the context of online and offline services. 


\section{Methods}

This research employs mixed method. According to Sarwono [17], mixed method is the use of two or more methods from two different approaches, qualitative and quantitative, of the research, the use of quantitative and qualitative data as empirical evidence, and answer of research problems as the researcher thinks that their findings are better, more complete, and more comprehensive. In this research, it is used concurrent triangulation strategy, which is according to Creswell [18] it is defined that "the researcher collects both quantitative and qualitative data concurrently and then compares the two databases to determine if there is convergence, differences, or some combination." It means in the concurrent triangulation; a research collects both qualitative and quantitative data simultaneously to be further used as the comparison and to determine whether there is either difference or combination from data processing.

Population of this research is 250 taxpayers registered in Large Tax Office 2. Sampling method is accidental sampling with sample size by 72 respondents. Accidental sampling method is actually based on convenience. Data collection is conducted using survey, in-depth interview, and literature study. Instrument for data collection is questionnaire distributed to taxpayers registered in Large Tax Office 2, while in-depth interview is conducted with academicians, practitioners, tax offices, and taxpayers.

Data analysis employs both quantitative and qualitative approaches. In analyzing quantitative data, this research used Microsoft Excel and SPSS 20 to conduct various tests such as validity test, reliability test, classical assumption test, descriptive analysis test, multiple regression, and coefficient determination test. In qualitative analysis, the research used transcript of in-depth interview and interpreted it along with other collected information. Result of the qualitative analysis would be used to complement and to cross-check the quantitative output.

\section{Analysis}

This research employs descriptive analysis to analyze data from each variable using mean value, which are modernization of tax administration and taxpayers' satisfaction. The following is the mean value of each variable.

Table 2. Descriptive Statistics

\begin{tabular}{|c|c|c|c|c|c|}
\hline & $\mathrm{N}$ & Minimum & Maximum & Mean & $\begin{array}{c}\text { Std. } \\
\text { Deviation }\end{array}$ \\
\hline $\begin{array}{l}\text { Modernization of Tax } \\
\text { Administration }\end{array}$ & 75 & 2,64 & 3,84 & 3,1884 & 29842 \\
\hline Taxpayer's Satisfaction & 75 & 2,29 & 4,00 & 3,0856 & ,32155 \\
\hline Valid N (listwise) & 75 & & & & \\
\hline
\end{tabular}

Source: SPSS (processed)

Standard deviation of modernization of tax administration is 0.298 , which is lower than mean value. It reflects that respondents expressed that respondents' answer regarding modernization of tax administration in Large Tax Office 2 is homogenous. Mean value of 
Modernization of Tax Administration is 3.19 within range $1-4$. According to the result, it can be interpreted that most of respondents preferred to agree on modernization of tax administration as mentioned in the questionnaire. In general, it expresses that the implementation of modernization of tax administration is considered fulfilling the target according to taxpayers registered in Large Tax Office 2.

variable taxpayers' satisfaction, standard deviation value is 0.322 , which is lower than the mean value. It shows that respondents' answer on satisfaction is homogenous. Mean value of taxpayers' satisfaction is 3.09 within range $1-4$. Based the result, most of respondents preferred to agree regarding taxpayers' satisfaction mentioned in the questionnaire. It means that taxpayers perceived satisfaction from quality of system, information, and services provided by Large Tax Office 2.

This research also conducted hypothesis test with simple linear regression using SPSS 20. The result is exhibited by the following table.

Table 3. Simple Linear Regression Output

\begin{tabular}{llccccc}
\hline Model & \multicolumn{2}{c}{$\begin{array}{c}\text { Unstandardized } \\
\text { Coefficients }\end{array}$} & $\begin{array}{c}\text { Standardized } \\
\text { Coefficients } \\
\text { Beta }\end{array}$ & t & Sig. \\
& B & Std. Error & , & & \\
\hline 1 & (Constant) & 1,151 &, 334 & & 3,449 &, 001 \\
& $\begin{array}{l}\text { Modernization of Tax } \\
\text { Administration }\end{array}$ &, 607 &, 104 &, 563 & 5,823 &, 000 \\
a. Dependent Variable: Taxpayers' Satisfaction & & & & \\
\hline
\end{tabular}

Source: SPSS (processed)

The hypothesis is tested to empirically reveal the impact of modernization of tax administration on taxpayers' satisfaction. The following is the statistical hypothesis of this research.

H0: $\beta=0 \quad$ Modernization of Tax Administration does not significantly affect taxpayers' satisfaction registered in Large tax Office 2

Ha: $\beta \neq 0 \quad$ Modernization of Tax Administration significantly affects taxpayers' satisfaction registered in Large tax Office 2

According to the result of linear regression analysis, it is seen that modernization of tax administration significantly affects taxpayers' satisfaction. It is proven by the significance value by 0.001 , which lower than alpha by 0.05 . Value of beta is 0.563 shows that there is strong relationship between modernization of tax administration and taxpayers' satisfaction. Positive value of beta indicates that the higher the implementation of modernization of tax administration, the higher the satisfaction of the taxpayers.

The result is consistent with the previous research from Abadi et al regarding the impact of quality of tax authority on taxpayers' satisfaction. In that research, the quality was indicated by procedures, facilities, human capital, attitude of tax authority, information quality, and service quality. Besides that, findings of this research are also relevant with research from Hanifah that modernization of tax administration significantly affects taxpayers' satisfaction.

This finding is confirmed by Gunadi [23] that modernization of tax administration would affect taxpayers' satisfaction. According to Gunadi, taxpayers would be satisfied if tax system transformed to be modern and simple. According to Inayati [24], modernization of tx administration is intended to improve services and to fix some weaknesses. If those objectives 
are achieved, taxpayers will be satisfied. Therefore, modernization of tax administration would deliver satisfaction for taxpayers if the objectives are well-achieved. According to Sugiharto [25] modernization of tax administration improves administration system and taxpayers' satisfaction. It is expressed from previous literatures.

Table 4 Coefficient Determination Test of Modernization of Tax Administration on Taxpayers' Satisfaction

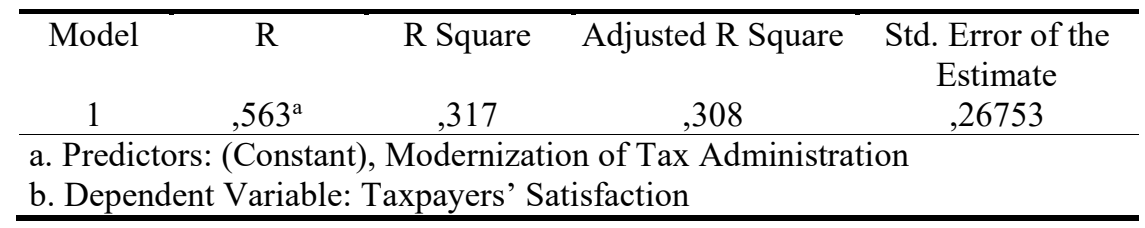

Source: SPSS (processed)

The table show $31.7 \%$ changes of taxpayers' satisfaction registered in Large Tax Office 2 is explained by modernization of tax administration. In other words, modernization of tax administration explains variation of changes of taxpayers' satisfaction registered in Large Tax Office 2 by $31.7 \%$, while the rest $68.3 \%$ are factors that are not observed in this research. This finding is consistent with research from Abadi et al that coefficient determination is averagely below $30 \%$.

According to Sugiharto, modernization of tax administration has started since 2002 where firstly implemented by Large Tax Office. The implementation has been running so far. Large Tax Office 2 has implemented the modernization policy accordingly. Pakpahan [26] there are five pillars that have to be sustained to implement tax reform, they are ideal organization structure, professional, competent, and credible human capital, reliable tax information system, simple business process, and law certainty. Therefore, Large Tax Office 2 needs to implement the modernization policy with high commitment and consistency.

Inayati, it requires technology utilization to improve quality of tax services of Directorate General of Tax (DGT) and Tax Offices. That way, process of tax payment can be done efficiently by "single-click" on smartphone instead of visiting the office only to pay the tax bill. Compared to services provided by private sector, services provided by tax authority is way left behind. For instance, when someone decides to do online shopping and payment, he/she just needs to simply use the smartphone. While process of tax administration, reporting, and payment of tax authority do not provide the similar services to taxpayers yet.

Pakpahan [26], expected goal from tax reform is strong (firmed) institutions, high credibility and accountability, effective and efficient business process, high compliance, and strategic synergy with other government institutions. Some problems taxpayers are still complaining about are ununiformed regulations and requirements of tax offices as well as interactive services and tax applications that are not optimal yet.

Satisfaction is one of important concerns of Tax Offices to improve voluntary compliance from taxpayers. Inayati expressed that satisfaction is strongly related with services and compliance. If services are well-improved, then satisfaction would improve as well. If satisfactions improve, then voluntary compliance would improve as well. Tax is actually a burden; thus Large Tax Office 2 needs to provide compensation in the form optimal services so that voluntary compliance can improve as well. 
It is also in line with Gunadi where satisfaction would increase confidence/trust. If taxpayers are satisfied, they would have strong confidence/trust towards Large Tax Office 2, and it would finally increase voluntary compliance. Therefore, Gunadi expressed that tax officials have to maintain their ethic codes in performing their duty.

According to in-depth interview with taxpayers, various aspect of modernization implemented by Large Tax Office 2 mostly run well. In terms of organization structure aspect, taxpayers perceived satisfaction upon services responsive and optimal services delivered by Large Tax Office 2. In regards with computerization aspect, taxpayers also satisfied upon the use of information and communication technology, thus tax administration procedure through application could be easily done. In the contest of human capital, taxpayers perceived satisfaction as tax officials are polite, welcome, and friendly.

According to in-depth interview with taxpayers registered in Large Tax Office 2, they still perceived some weaknesses. For instance, in regards with organization restructuration, requirement of each service is not complete yet. Moreover, in regards with human capital, interactive services (call center) are sometimes difficult to reach. In regards with computerization context, taxation application needs to be improved as many complaints come up from taxpayers.

\section{Conclusion}

According to the above result, it can be concluded some important findings regarding the impact of modernization of tax administration om taxpayers' satisfaction as follow.

1. Program of modernization of tax administration, started in 2002 with Large Tax Office as pilot project, did really help and ease taxpayers to meet their tax obligations. It is mainly due to gradual improvement on all aspects. The program of modernization also improves effectiveness and efficiency on performance of Large Tax Office 2. In general, modernization aspects of Large Tax Office 2 in the form of organization restructuration, improvement of human capital, and computerization has been running accordingly indicated by fewer number of complaints from taxpayers. In regards with organization structure, debureaucratization has played significant role to provide fast, simple, and easy services. Nevertheless, tax offices need to clear up the requirements and regulations to make it easier to understand for taxpayers. In regards with human capital, officials of Large Tax Office 2 are chosen people as they have high competencies and professionalism, politeness, responsibility, apply ethic code, and are service-oriented. However, it is sometimes difficult to reach interactive services (call center). In regards with computerization aspects, Large Tax Office 2 has used optimal information and communication technology as Large Tax Office was the one that implemented modernization as the pilot project among other tax offices. Therefore, cost and time efficiency also improved as well. It is just the application that needs more improvement based on number of complaints from taxpayers.

2. According to regression analysis result, it can be concluded that modernization of tax administration significantly affects taxpayers' satisfaction by 0.563 . Taxpayers' satisfaction increases as modernization program improves services in the form of organization structure, optimal utilization of communication and information technology, and improvement on quality of human capital. In regards with organization structure, taxpayers perceived satisfaction as Large Tax Office 2 provides easy and 
responsive services. In the context of computerization, taxpayers perceived satisfaction upon the use of communication and information technology so that tax administration process through application can be easily done. In regards with human capital, taxpayers perceived satisfaction as officials of Large Tax Office 2 performed high integrity, politeness, responsibility, and friendly services to taxpayers.

\section{References}

[1] L. Pandiangan, Modernisasi \& Reformasi Pelayanan Perpajakan. Elex Media Komputindo, 2013.

[2] J. Carlos Pinho, M. de Lurdes Martins, and I. Macedo, "The effect of online service quality factors on internet usage: the web delivery system of the taxation department," Int. J. Qual. Reliab. Manag., vol. 28, no. 7, pp. 706-722, 2011.

[3] R. M. Bird, "Administrative dimensions of tax reform," Asia-Pacific tax Bull., vol. 10, no. 3, pp. 134-150, 2004.

[4] C. Nasucha, "Reformasi Administrasi Publik: Teori dan Praktik, Jakarta: PT," Gramedia Widiasarana Indones., 2004.

[5] R. Khadka and G. Jenkins, "Modernization of tax administration in low income countries: The case of Nepal," JDI Executive Programs, 2000.

[6] A. Moradi-Abadi, A. Moradi-Abadi, and A. Jafari, "Innovation acceptance and customer satisfaction. A survey on tax information systems," AD-minister, no. 30, pp. 149-171, 2017.

[7] C.-W. Chen, "Impact of quality antecedents on taxpayer satisfaction with online tax-filing systems-An empirical study," Inf. Manag., vol. 47, no. 5-6, pp. 308-315, 2010.

[8] J. K. Puthur, L. Mahadevan, and A. P. George, "Tax payer Satisfaction and Intention to Re-use Government site for E-filing," Editor. Team Editor. Advis. Board, p. 46, 2015.

[9] R. R. Nelson, P. A. Todd, and B. H. Wixom, "Antecedents of information and system quality: an empirical examination within the context of data warehousing," J. Manag. Inf. Syst., vol. 21, no. 4, pp. 199-235, 2005.

[10] Z. Yang, S. Cai, Z. Zhou, and N. Zhou, "Development and validation of an instrument to measure user perceived service quality of information presenting web portals," Inf. Manag., vol. 42, no. 4, pp. 575-589, 2005.

[11] J. W. Palmer, "Web site usability, design, and performance metrics," Inf. Syst. Res., vol. 13, no. 2 , pp. 151-167, 2002.

[12] W. J. Doll and G. Torkzadeh, "The measurement of end-user computing satisfaction," MIS Q., pp. 259-274, 1988 .

[13] A. Rai, S. S. Lang, and R. B. Welker, "Assessing the validity of IS success models: An empirical test and theoretical analysis," Inf. Syst. Res., vol. 13, no. 1, pp. 50-69, 2002.

[14] A. G. A. Ilhaamie, "Service quality in Malaysian public service: some findings," Int. J. Trade, Econ. Financ., vol. 1, no. 1, p. 40, 2010.

[15] A. Parasuraman, V. A. Zeithaml, and L. L. Berry, "Servqual: A multiple-item scale for measuring consumer perc," J. Retail., vol. 64, no. 1, p. 12, 1988.

[16] P. J. Hu, S. A. Brown, J. Y. L. Thong, F. K. Y. Chan, and K. Y. Tam, "Determinants of service quality and continuance intention of online services: The case of eTax," J. Am. Soc. Inf. Sci. Technol., vol. 60, no. 2, pp. 292-306, 2009.

[17] J. Sarwono, "Strategi Melakukan Riset," Cet. I, 2013.

[18] J. W. Creswell and J. D. Creswell, Research design: Qualitative, quantitative, and mixed methods approaches. Sage publications, 2017. 